\title{
Characteristics and Distribution of Extracellular Proteases from Aeromonas hydrophila
}

\author{
By K.-Y. LEUNG $\dagger$ AND R. M. W. STEVENSON* \\ Department of Microbiology, College of Biological Science, University of Guelph, Guelph, \\ Ontario, Canada NIG 2WI
}

(Received 19 June 1987; revised 1 September 1987)

\begin{abstract}
The major extracellular proteases of Aeromonas hydrophila NRC 505 and ATCC 7966 are a thermostable metallo-protease (TSMP) and a thermolabile serine-protease (TLSP), respectively. The purified enzymes differed in sensitivity to heating at $56^{\circ} \mathrm{C}$ for $30 \mathrm{~min}$, in response to the inhibitors EDTA and phenylmethylsulphonyl fluoride (PMSF), and were antigenically distinct. When crude extracellular products (ECP) of 47 strains of $A$. hydrophila were screened, 27 strains produced both TSMP and TLSP. TSMP was the only extracellular protease produced by 19 strains, whereas only $A$. hydrophila ATCC 7966 produced TLSP as its sole protease. This distribution of protease enzymes among strains explains conflicting reports from studies in which single strains of $A$. hydrophila were examined. The TLSP of $A$. hydrophila was similar to the protease of $A$. salmonicida. Either or both TSMP and TLSP were produced by some strains of $A$. sobria and $A$. caviae.
\end{abstract}

\section{INTRODUCTION}

Aeromonas hydrophila produces a variety of extracellular products (ECP), including toxins, haemolysins and proteases (Ljungh \& Wadstrom, 1982), which may contribute to the virulence of this bacterium for fish and other hosts. The effects of proteases can include direct tissue damage, enhanced invasiveness or provision of nutrients, some of which have been suggested in the case of another fish pathogen, Aeromonas salmonicida (Sakai, 1985a,b). Other effects may be indirect, as, for example, by proteolytic activation of the aerolysin toxin precursor of $A$. hydrophila (Howard \& Buckley, 1985).

We have been interested in defining the role of proteases in $A$. hydrophila infections of fish. A significant problem in such studies is the disparity between reports of the numbers and types of enzymes produced by $\boldsymbol{A}$. hydrophila. For example, Gross \& Coles (1969), Allan \& Stevenson (1981) and Kanai \& Wakabayashi (1984) identified one protease from isolates of $A$. hydrophila. Dahle (1971) purified two proteases from A. hydrophila ATCC 14715, whereas two and, subsequently, three proteases were reported from $A$. hydrophila AH22 by Thune et al. (1982) and Amborksi et al. (1984). Denis \& Veillet-Poncet (1984) found several proteases in strain P50. Moreover, Nieto \& Ellis (1986) detected four or five zones of proteolytic activity with isoelectric focusing in crude extracts from strain B51. Unfortunately, these investigators worked on diferent strains of $A$. hydrophila, and in each case only a single strain was completely examined. The use of different media and growth conditions, and a variety of assay and purification procedures also make the literature reports very difficult to interpret and compare.

The objective in this work was to assess the extent of differences in the proteases produced by strains of $A$. hydrophila, by making direct comparisons on many isolates, grown under uniform

† Present address: Department of Microbiology and Immunology, University of Kentucky College of Medicine, Lexington, KY 40536-0084, USA.

Abbreviations: ECP, extracellular products; PMSF, phenylmethylsulphonyl fluoride; TLSP, thermolabile serine-protease; TSMP, thermostable metallo-protease. 
cultural conditions. To provide a better basis for comparison of the proteases, a combination of inhibition patterns and thermostability characteristics was used (see Dahle, 1971: Thune et al., 1982; Nieto \& Ellis, 1986). In addition, it was recognized that serological comparisons were essential, which required purification of proteases. After initial characterization of purified enzymes, it was established that the serological and functional tests could be done on crude ECP, allowing the examination of enough strains to establish a general picture of protease enzyme distribution in motile aeromonads.

\section{METHODS}

Bacterial strains. Strain numbers for the 47 A. hydrophila strains and 29 other aeromonads examined are given in Table 1. The majority were fish isolates; others were derived from water, animal or human sources. Isolates were tested using standard biochemical tests, and their identities confirmed according to the results given by Popoff (1984). Strains were stored at $15^{\circ} \mathrm{C}$ in tightly sealed slants of tryptic soy agar (TSA, Gibco). For protease production, cultures were grown at $25^{\circ} \mathrm{C}$ on brain heart infusion-skim milk agar (Allan \& Stevenson, 1981).

Protease assays. The buffer used for assays and all enzyme purification steps was $0.01 \mathrm{M}$-sodium phosphate, incorporating $0.5 \mathrm{~mm}-\mathrm{CaCl}_{2}$, at $\mathrm{pH} 7 \cdot 2$. During protease purifications, proteolytic activity was measured using Azocoll substrate (50-100 mesh) obtained from Calbiochem, following the procedure described by Allan \& Stevenson (1981). Azocasein (Sigma) was a more convenient substrate for thermostability and inhibitor studies. Buffer $(2.3 \mathrm{ml})$, enzyme sample $(0.1 \mathrm{ml})$ and $0.1 \mathrm{ml}$ Azocasein stock solution $(10 \%, \mathrm{w} / \mathrm{v})$ were added to each tube, and mixed. After $1 \mathrm{~h}$ incubation at $37^{\circ} \mathrm{C}$, the reaction was stopped by adding $2.5 \mathrm{ml} 10 \%(\mathrm{w} / \mathrm{v}) \mathrm{TCA}$. After an additional $30 \mathrm{~min}$ at room temperature, the precipitate was removed by centrifugation at $10000 \mathrm{~g}$ for $10 \mathrm{~min}$ at $4{ }^{\circ} \mathrm{C}$. Equal volumes $(1 \mathrm{ml})$ of the supernate and $1 \mathrm{M}-\mathrm{NaOH}$ were mixed and the absorbance read at $450 \mathrm{~nm}$ on a Bausch \& Lomb Spectronic 70 spectrophotometer. A blank was prepared using an enzyme sample inactivated by boiling for $10 \mathrm{~min}$. Proteolytic activity is expressed as $\mathrm{mg}$ Azocasein hydrolysed $\mathrm{h}^{-1}$.

\section{Table 1. Strains of Aeromonas examined}

\begin{tabular}{|c|c|c|}
\hline Taxon & Source* & Strain designation \\
\hline A. hydrophila & $\begin{array}{l}\text { ATCC } \\
\text { CDC } \\
\text { DMG } \\
\text { FHRL } \\
\text { NCMB } \\
\text { NHW } \\
\text { NRC } \\
\text { NRS } \\
\text { NZ } \\
\text { UM } \\
\text { UV }\end{array}$ & $\begin{array}{l}7966^{t}, 9071,14715 \\
3312.66,3314.66,3329.66,4167.66,5039.67,1625.70,1626.70,1627.70, \\
1628.70,1631.70,3250.71,3253.71,5736.71,232.76 \\
518, \text { FORD, G55 } \\
1.19,1.20,1.23 \\
1134 \\
76-388 \\
505 \\
\text { 35, TS-AH } \\
70-856,70-2234,70-4517, \text { B59, EGG } \\
\text { Bal, Ba5, Ba6, Sau-1, TF7 } \\
18,43,53,57,67,70,93,108, \text { N35 }\end{array}$ \\
\hline A. caviae & $\begin{array}{l}\text { CDC } \\
\text { ATCC } \\
\text { DMG } \\
\text { HSC } \\
\text { UM }\end{array}$ & $\begin{array}{l}3331.68,3402.68,1276.69,1629.70 \\
15467,15468^{\prime} \\
\text { ONT396-4K } \\
\text { G39 } \\
\text { Pis-1 }\end{array}$ \\
\hline A. sobria & $\begin{array}{l}\text { CDC } \\
\text { FHRL } \\
\text { UV } \\
\text { UM }\end{array}$ & $\begin{array}{l}1624.70,3251.71,3252.71,3254.71,5732.71 \\
1.40 \\
66,148,151,152,153,155,162,163,174 \\
\text { OU2 }\end{array}$ \\
\hline A. media & ATCC & $33907^{\prime}$ \\
\hline $\begin{array}{l}\text { A. salmonicida } \\
\text { t, Type strain } \\
\text { * Sources: A } \\
\text { Control, Atlant } \\
\text { FHRL, US Na } \\
\text { Children, Toro } \\
\text { Station, Nanain } \\
\text { Montreal, PQ, } \\
\text { Bacteria, Aber }\end{array}$ & $\begin{array}{l}\text { OMNR } \\
\text {, Americ } \\
\text { a., USA; } \\
\text { l Fish He } \\
\text { Canada; } \\
\text { C, Canad } \\
\text { ada; UV, } \\
\text { UK; N }\end{array}$ & $\begin{array}{l}\text { Culture Collection, Rockville, Md., USA; CDC, Centers for Disease } \\
\text { Department of Microbiology, University of Guelph, Ontario, Canada; } \\
\text { earch Laboratory, Kearneysville, W. Va., USA; HSC, Hospital for Sick } \\
\text { Vational Research Council, Ottawa, Canada; NRS, Pacific Biological } \\
\text { isheries Research Division, Wellington, New Zealand; UM, Universite de } \\
\text { sity of Victoria, BC, Canada; NCMB, National Collection of Marine } \\
\text { partment of National Health and Welfare, Ottawa, Canada; OMNR, } \\
\text { s, Guelph, Canada. }\end{array}$ \\
\hline
\end{tabular}


Inhibitor and heat-treatment effects. The inhibitors used (all obtained from Sigma) and their final concentrations are noted later. From stock solutions, $0.1 \mathrm{ml}$ samples of the inhibitors were added to the assay buffer and enzyme, and the mixture was pre-incubated at $22^{\circ} \mathrm{C}$ for $30 \mathrm{~min}$ before addition of Azocasein. For heat inactivation, the enzyme preparation was held in a water bath at $56^{\circ} \mathrm{C}$ for $30 \mathrm{~min}$, followed by cooling to $4{ }^{\circ} \mathrm{C}$ before addition of Azocasein. The total assay volume in each case was $2.5 \mathrm{ml}$; all assays were done in duplicate.

ECP preparation. Brain heart infusion-skim milk agar $(200 \mathrm{ml})$ was solidified in a $23 \times 23 \mathrm{~cm}$ pan, then overlaid with a $24 \times 24 \mathrm{~cm}$ sheet of sterile dialysis membrane with a molecular mass exclusion size of $12000-14000$ (Spectrum Medical Industries). The membrane surface was inoculated by spreading with $1 \mathrm{ml}$ of an $18 \mathrm{~h}$ bacterial culture. After $36 \mathrm{~h}$ at $25^{\circ} \mathrm{C}$, the growth was washed from the dialysis membrane with $20 \mathrm{ml}$ buffer. Bacterial cells were removed by centrifugation for $30 \mathrm{~min}$ at $27000 \mathrm{~g}$ and the supernatant was filtered through a $0.45 \mu \mathrm{m}$ filter (Gelman Sciences). This filtrate was the ECP preparation used in subsequent work.

Protease purification. A $20 \mathrm{ml}$ volume of ECP was added to $50 \mathrm{ml}$ DEAE-cellulose (Whatman; DE52) in a porcelain funnel and batch-eluted with $20 \mathrm{ml}$ of buffer. Acetone $\left(5\right.$ vols), pre-chilled to $20^{\circ} \mathrm{C}$, was added with slow stirring, and the precipitate collected by centrifugation at $12000 \mathrm{~g}$ for $10 \mathrm{~min}$. The acetone was decanted and the pellet redissolved in $10 \mathrm{ml}$ of buffer. This was applied to a $2.5 \times 100 \mathrm{~cm}$ column of Sephacryl S-300 (Pharmacia), previously calibrated by using Blue Dextran and Pharmacia molecular mass markers. Eluted fractions were collected and assayed for protein $\left(A_{280}\right)$ and proteolytic activity. Pooled fractions with proteolytic activity were concentrated by acetone precipitation. A sample $(2 \mathrm{ml})$ of the redissolved precipitate was applied to a polyacrylamide gel for zone electrophoresis, using a $3 \%(\mathrm{w} / \mathrm{v})$ spacing gel and a $5 \%(\mathrm{w} / \mathrm{v})$ resolving gel, and $0.05 \mathrm{M}$-Tris/0.38 M-glycine buffer ( $\mathrm{pH} \mathrm{8.3).} \mathrm{After} \mathrm{electrophoresis,} \mathrm{the} \mathrm{gel} \mathrm{was} \mathrm{cut} \mathrm{into} \mathrm{horizontal} \mathrm{strips} \mathrm{of} 2-3 \mathrm{~mm}$. Each strip was allowed to elute into $5 \mathrm{ml}$ of buffer for $18 \mathrm{~h}$ at $4{ }^{\circ} \mathrm{C}$, then protease activity was located by Azocoll assay.

SDS-PAGE. Enzyme samples were denatured and run on SDS-PAGE, according to the procedure of Laemmli (1970). The proteins were silver-stained (Bio-Rad kit) and the molecular masses determined by comparison with sets of high and low molecular mass calibration markers (Pharmacia).

Serological tests. A sample of purified protease, containing $200-300 \mu \mathrm{g}$ protein in $5 \mathrm{ml}$, was emulsified in an equal volume of Freund's complete adjuvant (Calbiochem). A New Zealand White rabbit was injected intramuscularly with $1 \mathrm{ml}$ of the preparation. The injection regime was repeated at 1 week intervals for 4 weeks. Collected serum was tested by the precipitin ring reaction. For immunodiffusion assays, a $1 \%(w / v)$ agarose solution was made by melting in Bio-Rad immunoelectrophoresis buffer IV, pH 8.6, and $50 \mathrm{ml}$ was cast onto a glass plate $(15 \times 20 \mathrm{~cm})$. After wells were cut and samples added, the agarose plates were incubated at $37^{\circ} \mathrm{C}$ in a humidity chamber for $24 \mathrm{~h}$. In addition to the immunodiffusion assays illustrated, series of wells with the reference antigen flanking each sample were used to determine reactions of identity or partial identity.

\section{RESULTS}

\section{Protease purification and characteristics}

Approximately $10 \%$ of the original proteolytic activity was recovered from the ECP of $A$. hydrophila NRC 505 and ATCC 7966, with a purification of 26-fold for $A$. hydrophila NRC 505 and 43-fold for ATCC 7966. As DEAE-cellulose (anion exchange) chromatography resulted in a loss of $30 \%$ of the activity of the NRC 505 enzyme, with no increase in specific activity, the step was not used for purifying the enzyme of $A$. hydrophila ATCC 7966. All of the proteolytic activity, from either strain, was eluted from the Sephacryl S-300 column in association with the second of three protein peaks (Fig. 1). However, elution positions suggested enzymes of different molecular masses. The protease of $\boldsymbol{A}$. hydrophila ATCC 7966 had an estimated molecular mass of $145 \mathrm{kDa}$ (Fig. 1 a), whereas that of NRC 505 was $54 \mathrm{kDa}$ (Fig. $1 b$ ). Proteolytic fractions migrated very slowly in a non-denaturing polyacrylamide gel, remaining near the top of the gel. Significant activity was lost in zone electrophoresis ( 50 to $80 \%$ ), but there was a compensating increase in specific activities. After this step, both protease preparations appeared as single protein bands in SDS-polyacrylamide gels (Fig. 2).

The SDS-PAGE bands again suggested that the proteases of the two strains differed in molecular mass: $35 \mathrm{kDa}$ for the A. hydrophila NRC 505 enzyme, and $68 \mathrm{kDa}$ for that of ATCC 7966 (Fig. 2). As the values from denaturing gels were about half those determined by gel filtration, both proteases may be dimers. Although the different molecular masses suggested different protease enzymes, substrate specificities did not appear to differ. The ECP of $A$. hydrophila NRC 505 and ATCC 7966 both hydrolysed a wide spectrum of proteins, including, in order of preference, casein, gelatin, haemoglobin and elastin. 


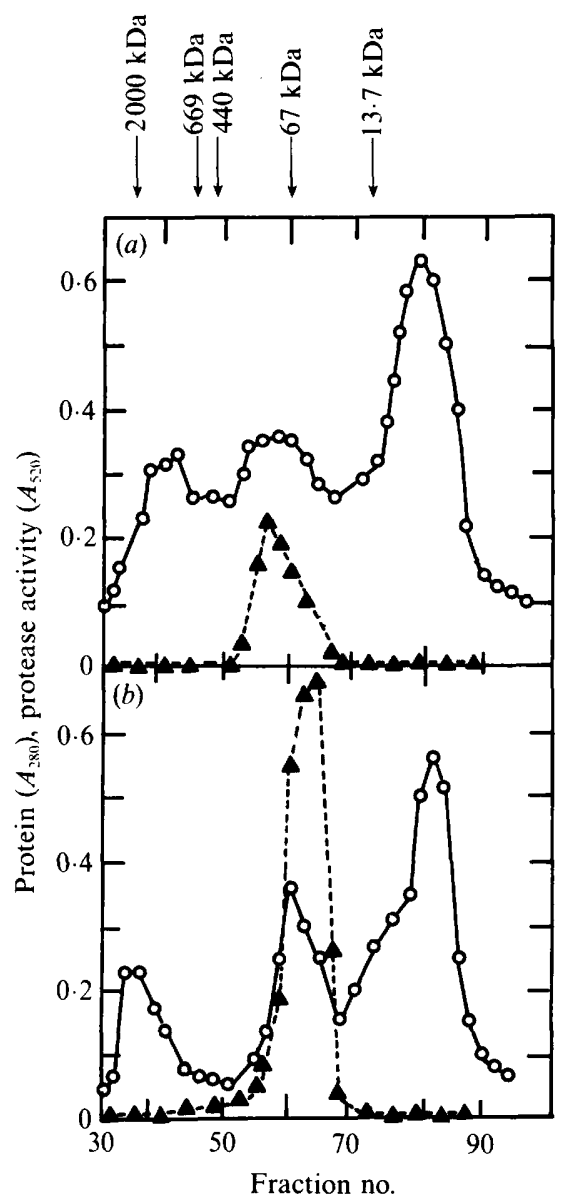

Fig. 1. Elution of extracellular proteases of $A$. hydrophila from a Sephacryl S-300 column. The column was loaded with samples containing approximately $100 \mathrm{mg}$ protein, which had been collected as an acetone-precipitate from the ECP of $(a) A$. hydrophila ATCC 7966 and $(b) A$. hydrophila NRC 505. Elution positions for molecular mass markers are indicated by arrows : thyroglobulin, $669 \mathrm{kDa}$; ferritin, $440 \mathrm{kDa}$; albumin, $67 \mathrm{kDa}$; ribonuclease A, $13.7 \mathrm{kDa}$; and Blue Dextran, $2000 \mathrm{kDa}$. Protease activity (A) was measured by the Azocoll assay, read as absorbance at $520 \mathrm{~nm}$. Protein $(O)$ was read as the absorbance of collected fractions at $280 \mathrm{~nm}$.

\section{Inhibitor and heat-stability studies}

Purified protease from $A$. hydrophila NRC 505 was inhibited by the metal-ion chelators EDTA and 1,10-phenanthroline, and by the thiol compounds cysteine and DTT, but not by PMSF, a serine-protease inhibitor (Table 2). Approximately $75 \%$ of proteolytic activity remained after heating at $56{ }^{\circ} \mathrm{C}$ for $30 \mathrm{~min}$. In contrast, purified protease from $A$. hydrophila ATCC 7966 was inhibited by PMSF but not by metal-ion chelators, and the activity was heatlabile (Table 2). Thus, the proteases of these two strains of $A$. hydrophila differed in activity as well as in size. The responses of unpurified proteolytic activities in the ECP of $A$. hydrophila NRC 505 and ATCC 7966 to inhibitors and heat-inactivation were the same as their respective purified counterparts (Table 2).

\section{Serology}

Antiserum raised against the protease from $A$. hydrophila ATCC 7966 produced a precipitin band with ECP from that strain, but not with the ECP produced by NRC 505 (Fig. 3A). 


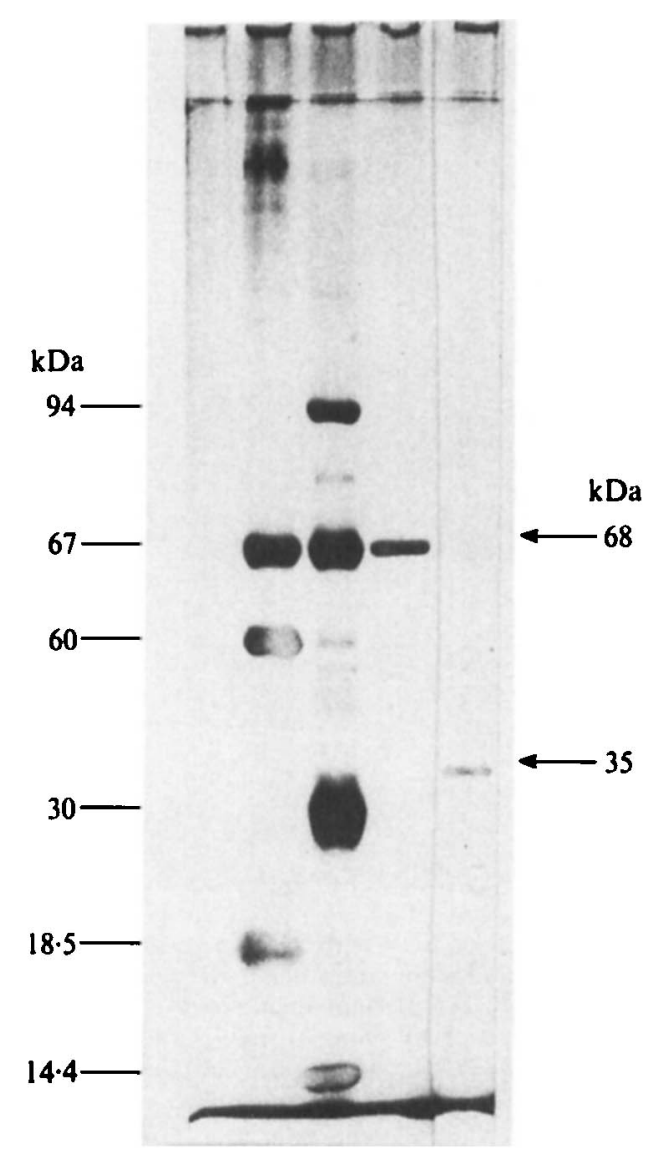

Fig. 2. SDS-PAGE of purified proteases of $A$. hydrophila strains NRC 505 and ATCC 7966. High molecular mass markers are in lane 1 ; ferritin $(18.5 \mathrm{kDa})$, catalase $(60 \mathrm{kDa})$ and albumin $(67 \mathrm{kDa})$. Low molecular mass markers are in lane 2 ; phosphorylase $B(94 \mathrm{kDa})$, albumin $(67 \mathrm{kDa})$, carbonic anhydrase $(30 \mathrm{kDa})$ and $\alpha$-lactalbumin $(14.4 \mathrm{kDa})$. Lane 3 , protease purified from $A$. hydrophila ATCC 7966. Lane 4, protease purified from $A$. hydrophila NRC 505.

Similarly, antiserum to the protease from $A$. hydrophila NRC 505 reacted with ECP from its homologous strain, but not with the ECP produced by ATCC 7966 (Fig. 3B). No trace amounts of ATCC 7966 protease were detected in the ECP of $A$. hydrophila NRC 505, or vice versa, by immunodiffusion assay (Fig. 3), nor by rocket immunoelectrophoresis. The latter procedure was also used to determine that $A$. hydrophila ATCC 7966 and NRC 505 each produced only a single type of protease regardless of the stage of growth at which the ECP were collected $(12-61 \mathrm{~h}$ at $\left.25^{\circ} \mathrm{C}\right)$.

\section{Proteases from A. hydrophila Ba5}

The ECP from a highly proteolytic strain, $A$. hydrophila $\mathrm{Ba5}$, had a response pattern to inhibitors and heat-treatment that was a mixture of the characteristics of the ECP produced by $A$. hydrophila NRC 505 and ATCC 7966 (Table 2). In immunodiffusion tests, ECP from $A$. hydrophila $\mathrm{Ba} 5$ reacted with both anti-ATCC-7966-protease and anti-NRC-505-protease sera (Fig. 3A, B). With a mixture of both antisera, two distinct precipitin bands formed (Fig. 3C). Subsequently, one of the proteases was purified from the ECP of $\mathrm{Ba} 5$ on a single-step gelatinagarose affinity column, eluted with $0.2 \mathrm{M}$-EDTA. This enzyme was similar to the NRC 505 enzyme in its response to inhibitors and heating (Table 2), and was antigenically identical. The 


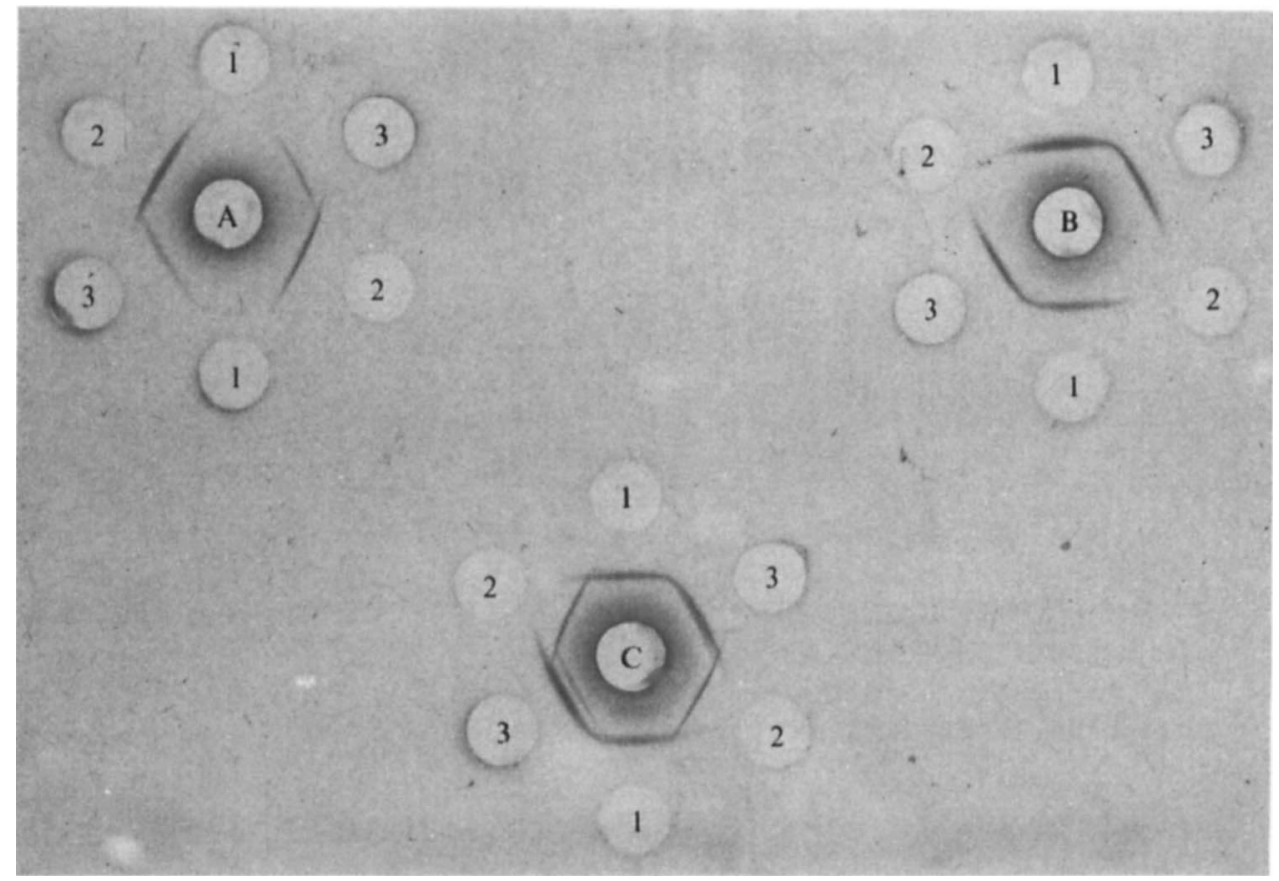

Fig. 3. Ouchterlony immunodiffusion of ECP with antisera raised against purified proteases. The centre wells contained $10 \mu$ of undiluted rabbit antiserum to the protease of $A$. hydrophila ATCC 7966 (A), the protease of $A$. hydrophila NRC 505 (B) or a mixture of equal volumes of the two sera (C). The outer wells contained $10 \mu \mathrm{l}$ samples of ECP from $A$. hydrophila NRC 505 (1), and $A$. hydrophila ATCC 7966 (2) or $A$. hydrophila Ba5 (3). The plate was incubated at $37^{\circ} \mathrm{C}$ for $24 \mathrm{~h}$.

Table 2. Effects of inhibitors and heat-treatment on proteolytic activities of ECPs and purified enzymes from A. hydrophila NRC 505, ATCC 7966 and Ba5

ECP or PP were pre-incubated with the inhibitors or substrates for $30 \mathrm{~min}$ before addition of Azocasein substrate. ECP are a cell-free filtrate, collected after growth of $A$. hydrophila for $36 \mathrm{~h}$ on brain heart infusion-skim milk agar; PP indicates proteases purified from $A$. hydrophila NRC 505 and ATCC 7966 by gel filtration and zone electrophoresis, and from $A$. hydrophila $\mathrm{Ba} 5$ by gelatin-agarose affinity chromatography.

\begin{tabular}{|c|c|c|c|c|c|c|}
\hline \multirow[b]{3}{*}{ Treatment } & \multicolumn{6}{|c|}{ Proteolytic activity remaining $(\%)$ in:* } \\
\hline & \multicolumn{2}{|c|}{ NRC 505} & \multicolumn{2}{|c|}{ ATCC 7966} & \multicolumn{2}{|c|}{ Ba5 } \\
\hline & ECP & PP & ECP & PP & $\mathrm{ECP}$ & PP \\
\hline EDTA $(10 \mathrm{mM})$ & $2 \cdot 3$ & $4 \cdot 2$ & $90 \cdot 3$ & $98 \cdot 8$ & $41 \cdot 3$ & $4 \cdot 5$ \\
\hline 1,10-Phenanthroline $(10 \mathrm{~mm})$ & $8 \cdot 3$ & $5 \cdot 3$ & $91 \cdot 9$ & 97.6 & $32 \cdot 4$ & $5 \cdot 6$ \\
\hline Cysteine ( $5 \mathrm{~mm})$ & $36 \cdot 4$ & $8 \cdot 3$ & $69 \cdot 4$ & $72 \cdot 1$ & $73 \cdot 8$ & $18 \cdot 2$ \\
\hline DTT $(10 \mathrm{~mm})$ & $4 \cdot 6$ & $4 \cdot 2$ & $41 \cdot 9$ & $58 \cdot 1$ & $28 \cdot 7$ & $12 \cdot 1$ \\
\hline Soy bean trypsin inhibitor $\left(1 \mathrm{mg} \mathrm{ml}^{-1}\right)$ & $95 \cdot 4$ & $100 \cdot 0$ & $96 \cdot 8$ & 91.9 & $96 \cdot 7$ & $101 \cdot 5$ \\
\hline Lima bean trypsin inhibitor $\left(1 \mathrm{mg} \mathrm{ml}^{-1}\right)$ & $95 \cdot 4$ & $100 \cdot 0$ & $96 \cdot 8$ & $97 \cdot 7$ & $100 \cdot 0$ & $98 \cdot 5$ \\
\hline$\varepsilon$-Aminocaproic acid $\left(1 \mathrm{mg} \mathrm{ml}^{-1}\right)$ & $93 \cdot 2$ & $100 \cdot 0$ & $98 \cdot 4$ & $98 \cdot 8$ & $100 \cdot 8$ & $100 \cdot 1$ \\
\hline PMSF (1 mM) & $97 \cdot 0$ & $94 \cdot 7$ & $4 \cdot 2$ & 1.2 & $71 \cdot 7$ & $118 \cdot 6$ \\
\hline $56{ }^{\circ} \mathrm{C}, 30 \mathrm{~min}$ & $63 \cdot 6$ & $75 \cdot 0$ & $2 \cdot 7$ & 5.8 & $50 \cdot 0$ & $83 \cdot 6$ \\
\hline
\end{tabular}

* The remaining proteolytic activity is expressed as a percentage of the activity of an untreated sample on Azocasein substrate $\left(1 \mathrm{~h}\right.$ at $\left.37^{\circ} \mathrm{C}\right)$. Values are the mean of duplicate samples, with less than $5 \%$ deviation. 
(a)

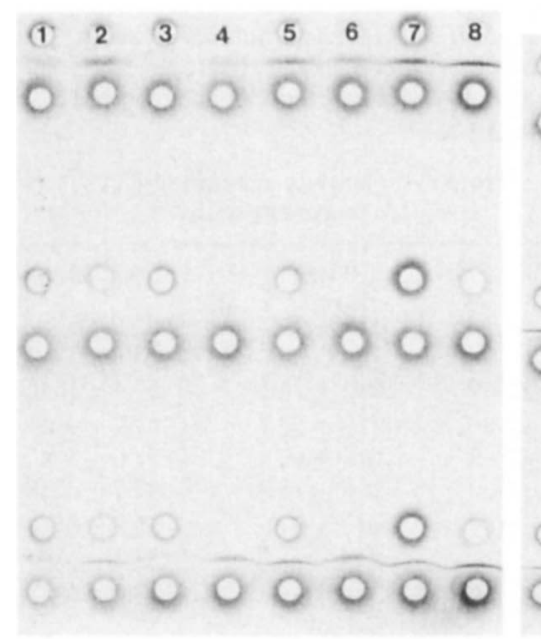

(b)

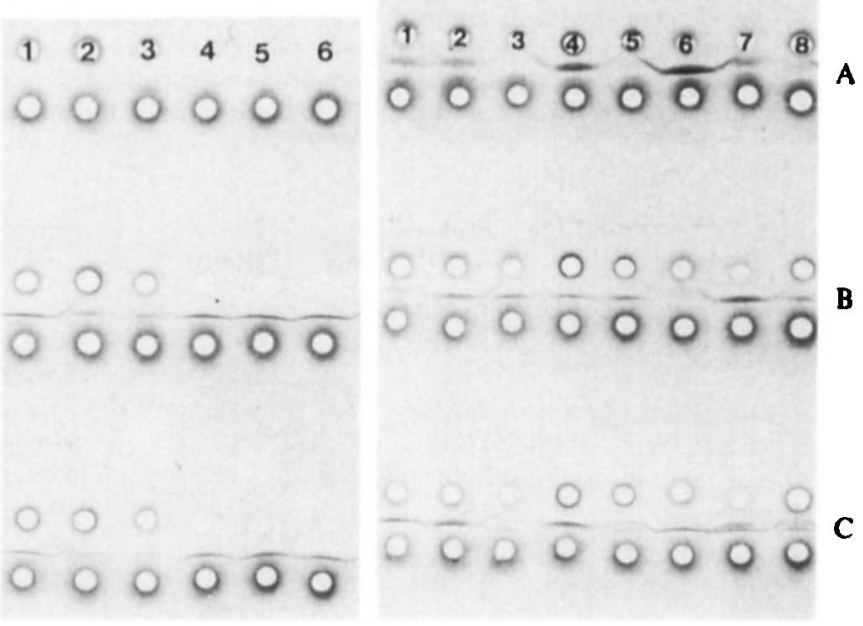

Fig. 4. Survey of TSMP and TLSP proteases in ECP of aeromonads by immunodiffusion. The top row of wells in each set contained $10 \mu \mathrm{l}$ of ECP, the lower wells contained $10 \mu \mathrm{l}$ of antisera, as follows: row A, anti-NRC-505-protease; row B, anti-ATCC-7966-protease; row C, mixture of the two antisera. Section $(a)$ shows ECP from strains of $A$. hydrophila with only the TSMP: 1 , NRC 505;2, DMG $518 ; 3$ NZ 70-4517; 4, FHRL 1.23; 5, FHRL $1.19 ; 6$, TF7; 7, Ba6; 8, Sau-1. Section $(b)$ strains have only TLSP: $1, A$. hydrophila ATCC $7966 ; 2, A$. sobria OU2; 3 , A. sobria CDC $3252.71 ; 4, A$. salmonicida OMNR 426; 5, A. salmonicida OMNR 357; 6, A. salmonicida As19. Section (c) strains produce both enzymes: $1, A$. hydrophila ATCC $14715 ; 2, A$. hydrophila FHRL $1.20 ; 3, A$. sobria FHRL $1.40 ; 4, A$. hydrophila Ba5; $5, A$. caviae Pis-1; 6, A. hydrophila NHW 76-388; 7, $A$. hydrophila NRS $35 ; 8, A$. hydrophila TS-AH.

second enzyme showed partial rather than complete identity with the ATCC 7966 protease (Fig. $3 \mathrm{~A}, \mathrm{C})$.

\section{Proteases of other strains of $A$. hydrophila}

When ECP from a total of 47 strains of $A$. hydrophila were screened with the two antisera, 19 reacted with anti-NRC-505-protease serum but not with anti-ATCC-7966-protease serum (Fig. $4 a$ ). With the NRC 505 enzyme, all strains gave reactions of complete identity except $A$. hydrophila ATCC 9071, which had a reaction of partial identity. Proteolytic activities of the ECP from these strains were all sensitive to EDTA, resistant to PMSF, and relatively heatstable (Table 3), as expected for the NRC 505 enzyme type. No other strain besides $A$. hydrophila ATCC 7966 produced ECP that reacted only with the anti-ATCC-7966-protease serum (Fig. 4b; Table 3). However, 27 strains of $A$. hydrophila gave a reaction with both antisera, and formed two precipitin bands with a mixture of the two sera (Fig. 4c). Of these strains, 10 produced an enzyme antigenically identical to that of ATCC 7966, while the others gave reactions of partial identity (Fig. $4 c$ ).

ECP from strains producing both enzymes gave intermediate responses to EDTA and PMSF inhibition and heat-inactivation of proteolytic activity (Table 3 ). The activity remaining after the treatments varied for different strains, depending upon the relative proportions of the two enzymes present. This was demonstrated by the responses of artificial mixtures of ECP from $A$. hydrophila ATCC 7966 and NRC 505, which produced mixed responses that were in proportion to the mixing ratios (Table 4). In addition, the relative amounts of the two proteases produced by different strains could be estimated serologically as there was a direct relationship between rocket height in immunoelectrophoresis and proteolytic activity for both enzymes. In tests on ECP from five strains that produced both enzymes, the relative proportions of the enzymes predicted by ratio of rocket heights and the responses to EDTA, PMSF and heating were relatively consistent with responses of the mixtures reported in Table 4 (data not shown). 
Table 3. Inhibitor and heat-stability of proteases in ECP of Aeromonas

ECP were assayed for proteolytic activity on Azocasein substrate, at $37^{\circ} \mathrm{C}$ for $1 \mathrm{~h}$. Before the assay, preparations were pre-incubated with $10 \mathrm{mM}$-EDTA or $1 \mathrm{mM}$-PMSF for $30 \mathrm{~min}$, or were heated at $56^{\circ} \mathrm{C}$ for $30 \mathrm{~min}$. Proteolytic activity remaining was calculated as a percentage of the activity of an untreated $\mathrm{ECP}$ sample. Values are the mean for all strains in the group, $\pm \mathrm{SD}$.

\begin{tabular}{|c|c|c|c|c|c|}
\hline \multirow[b]{2}{*}{ Taxon } & \multirow{2}{*}{$\begin{array}{l}\text { Protease } \\
\text { type* }\end{array}$} & \multirow{2}{*}{$\begin{array}{l}\text { No. of } \\
\text { strains }\end{array}$} & \multicolumn{3}{|c|}{$\begin{array}{l}\text { Proteolytic activity remaining }(\%) \\
\text { after treatment with: }\end{array}$} \\
\hline & & & EDTA & PMSF & $56^{\circ} \mathrm{C}, 30 \mathrm{~min}$ \\
\hline A. hydrophila & $\begin{array}{l}\text { TSMP } \\
\text { TLSP } \\
\text { Both }\end{array}$ & $\begin{array}{r}19 \\
1 \\
27\end{array}$ & $\begin{array}{l}10 \cdot 7 \pm 5 \cdot 1 \\
90 \cdot 5 \\
32 \cdot 1 \pm 14 \cdot 9\end{array}$ & $\begin{array}{l}87 \cdot 0 \pm 7 \cdot 8 \\
7 \cdot 4 \\
65 \cdot 1 \pm 20 \cdot 5\end{array}$ & $\begin{array}{l}62 \cdot 6 \pm 6 \cdot 3 \\
5 \cdot 4 \\
57 \cdot 4 \pm 16 \cdot 0\end{array}$ \\
\hline A. sobria & $\begin{array}{l}\text { TSMP } \\
\text { TLSP } \\
\text { Both }\end{array}$ & $\begin{array}{l}2 \\
2 \\
9\end{array}$ & $\begin{array}{l}23 \cdot 4 \pm 0.5 \\
91 \cdot 6 \pm 11 \cdot 8 \\
58.9 \pm 14 \cdot 0\end{array}$ & $\begin{array}{l}77 \cdot 9 \pm 17 \cdot 7 \\
10 \cdot 0 \pm 6 \cdot 2 \\
28 \cdot 9 \pm 15 \cdot 7\end{array}$ & $\begin{array}{l}91 \cdot 9 \pm 9 \cdot 2 \\
22 \cdot 6 \pm 8 \cdot 4 \\
47 \cdot 2 \pm 22 \cdot 0\end{array}$ \\
\hline A. caviae & $\begin{array}{l}\text { TSP } \\
\text { Both }\end{array}$ & $\begin{array}{l}2 \\
1\end{array}$ & $\begin{array}{l}50 \cdot 5 \pm 10 \cdot 9 \\
34 \cdot 8\end{array}$ & $\begin{array}{c}100 \cdot 4 \\
30 \cdot 4\end{array}$ 0.6 & $\begin{array}{l}85 \cdot 8 \pm 0 \cdot 7 \\
32 \cdot 6\end{array}$ \\
\hline A. salmonicida & TLSP & 3 & $87.9 \pm 14.9$ & $9 \cdot 0 \pm 5 \cdot 5$ & $15 \cdot 7 \pm 0.9$ \\
\hline
\end{tabular}

* Protease types in ECP were assigned on the basis of serological reactions with antisera against purified proteases: TSMP, ECP reacted with anti-NCR-505 serum; TLSP, ECP reacted with anti-ATCC-7966-serum; TSP, ECP did not give a reaction with either antisera.

Table 4. Response to inhibitors and heat-treatment of proteases in mixtures of ECP from A. hydrophila ATCC 7966 and NRC 505

Pre-treatments and determination of remaining activity were as described in Table 3.

$\overbrace{\text { NRC } 505}^{\begin{array}{c}\text { Components of } \\ \text { mixture }(\%, v / v)^{*}\end{array}} \begin{array}{c}\text { ATCC } 7966 \\ 100\end{array})$

$\begin{array}{ccc}\begin{array}{c}\text { Proteolytic activity remaining }(\%) \\ \text { after treatment with: }\end{array} \\ \overbrace{\text { EDTA }} & \text { PMSF } & 56{ }^{\circ} \mathrm{C}, 30 \mathrm{~min} \\ 3.6 & 89.0 & 64.6 \\ 17.1 & 67.0 & 58.5 \\ 29.4 & 64.7 & 55.3 \\ 36.1 & 59.0 & 51.8 \\ 47.2 & 49.4 & 40.4 \\ 57.1 & 35.7 & 32.1 \\ 67.5 & 30.0 & 30.0 \\ 75.8 & 15.2 & 18.2 \\ 92.8 & 3.6 & 5.4\end{array}$

* The ECP from cultures of $A$. hydrophila ATCC 7966 and NRC 505 were adjusted to equal concentrations of proteolytic activity $\left(50 \mathrm{mg}\right.$ Azocasein hydrolysed $\mathrm{h}^{-1}$ ).

\section{Proteases of other aeromonads}

The biochemical test reactions of the motile aeromonads selected for study indicated that 16 strains were $A$. sobria and 9 were $A$. caviae. Two strains of $A$. sobria produced only NRC-505-like proteases, which were EDTA-sensitive, PMSF-resistant and relatively heat-stable (Table 3). All but two other strains of $A$. sobria produced both enzymes (Table 3). The remaining two strains of A. sobria, OU2 and CDC 3252.71 , were of interest because their ECP reacted only with antiATCC-7966 serum, but in a reaction of partial identity (Fig. $4 a$ ). Similarly, three strains of $A$. salmonicida, included for comparison, gave a reaction of partial identity with anti-ATCC-7966protease, but no reaction with anti-NRC-505-protease (Fig. $4 b$ ). The precipitin bands of the strains of $A$. salmonicida and $A$. sobria joined, suggesting that they produced similar proteases that were antigenically related to that of $A$. hydrophila ATCC 7966. These enzymes resembled the ATCC 7966 enzyme in inhibitor and heat-treatment responses (Table 3). 
No protease activity could be detected in the extracellular products of six strains of $A$. caviae nor of $A$. media ATCC 33907. One strain of $A$. caviae, UV66, produced both enzymes. Two other strains of $A$. caviae, CDC 3331.68 and CDC 3402.68 , did not react with either antisera, but produced proteolytic activity in ECP that was moderately EDTA-resistant, PMSF-resistant and heat-stable (Table 3). This may be a third protease enzyme, of most significance in strains of $A$. caviae.

\section{DISCUSSION}

Two distinct types of extracellular proteases were produced by strains of $A$. hydrophila: a temperature-stable metallo-protease (TSMP) and a temperature-labile serine-protease (TLSP). These could be defined by a combination of the characteristics used by Thune et al. (1982) and Dahle (1971). The TSMP enzyme-type, produced by $A$. hydrophila NRC 505, was a metalloprotease, sensitive to EDTA, and stable on heating at $56^{\circ} \mathrm{C}$. In contrast, the extracellular protease of $A$. hydrophila ATCC 7966 was a serine-protease, sensitive to PMSF but not EDTA, and labile on heating at $56^{\circ} \mathrm{C}$ for $30 \mathrm{~min}$. In this study, it was demonstrated that the division, made on the basis of the functional criteria of inhibitors and heat-sensitivity, is consistent with antigenic characteristics of the two enzyme types.

Previous reports have described finding the TSMP alone (Gross \& Coles, 1969; Allan \& Stevenson, 1981; Denis \& Veillet-Poncet, 1984; Kanai \& Wakabayashi, 1984). Other studies have reported TSMP to be one of two proteases produced, the other being the TLSP (Dahle, 1971; Thune et al., 1982; Nieto \& Ellis, 1986). One evident source of the different results obtained in these studies is the initial choice of bacterial strain. The majority of the strains examined in this study, i.e. 27 of 47 , produced both protease types, but many (19 of 47) produced only the TSMP. Production of TLSP as the only protease was rare in A. hydrophila, with the type strain, ATCC 7966, being the sole example. Thune et al. (1982) and Amborski et al. (1984) reported three enzymes, based on differences in heat-stability. Other than the distinctly different protease of two strains of $A$. caviae, we did not find evidence of another major extracellular protease in the strains studied. However, proteases with more specific substratespecificities or induced by different growth conditions would not be detected in this study.

The TLSP of $A$. hydrophila is essentially the same as the major serine protease enzyme found in $A$. salmonicida (Fyfe et al., 1987), based on serological reactions and response to inhibitors and heat. Thus, this study is in agreement with the results of Dahle (1971), who first reported the similarity. For all three strains of $A$. salmonicida and two of the strains of $A$. sobria tested, the TLSP appeared to be the single major protease. Reactions of partial identity, seen in the serological tests, suggest that there are two antigenically related forms of the TLSP. The response of ECP from strains producing this enzyme alone ( $A$. hydrophila ATCC 7966 and three strains of $A$. salmonicida) do not suggest major differences in catalytic activity (Table 3 ), and the significance of the antigenic variation is not clear. The TSMP appeared less antigenically heterogeneous than the TLSP. Only $A$. hydrophila ATCC 9071 and two strains of $A$. sobria, FHRL1.40 and Pis-1, produced proteases which were partially rather than completely identical with the protease of NRC 505. Autolysis is a problem associated with studying protease enzymes, particularly in attempts to purify and characterize. This may be the source of some heterogeneity of serological reactions as well as variations in molecular sizes and numbers of enzyme forms reported in studies of both $A$. hydrophila (Nieto \& Ellis, 1986) and $A$. salmonicida (Fyfe et al., 1987). If the protease types of $A$. hydrophila had been designated on the basis of antigenicity alone, the variations indicated by reactions of partial identity would have suggested multiple forms. Protease typing using inhibitors and heat-stability in conjunction with serological studies allowed more useful categories of enzymes to be defined.

Because of autolysis and general loss of activity on purification, it was important that both the serological and functional tests could be done on crude ECP, with results consistent with those for purified enzymes. Previously, Thune et al. (1982) and Nieto \& Ellis (1986) used the effect of inhibitors and heating on crude extracts as an estimate of the proportions of protease present; our serological and mixing experiments confirm the use of this approach. However, the response of ECP to inhibitors can be difficult to interpret with reliability. 
This study clarifies the situation with regard to the number and types of extracellular proteolytic enzymes produced by strains of $A$. hydrophila. The functions of the enzymes, including their potential contributions to pathogenicity, remain undefined, and the question of why a strain might produce two forms of protease (Dahle, 1971) remains unanswered. Identification of the proteases produced by particular strains is an essential preliminary to answering such questions. ECP from $A$. hydrophila have been shown to have toxic effects when injected into fish (Allan \& Stevenson, 1981: Thune et al., 1982). However, Trust (1986) has emphasized that the contribution of an enzyme or toxin to virulence must be confirmed by studies with bacterial mutants, deficient in the specific exo-products. We have used the information obtained about protease distribution to select a virulent strain of $A$. hydrophila that produced only a single protease, and to produce protease-deficient mutants for virulence studies (Leung, 1987).

This research was supported by an Operating Grant from the Natural Sciences and Engineering Research Council of Canada to R.M.W.S. K.-Y.L. was a research student supported by a grant from the Ontario Ministry of Natural Resources. We are grateful to Dr R. J. Douglas and Dr J. Lam for helpful comments on the serological studies.

\section{REFERENCES}

Allan, B. J. \& Stevenson, R. M. W. (1981). Extracellular virulence factors of Aeromonas hydrophila in fish infections. Canadian Journal of Microbiology 27, 1114-1122.

AMborski, R. L., Borall, R. \& Thune, R. L. (1984). Effects of short-term storage on recovery of proteases from extracellular products of Aeromonas hydrophila. Applied and Environmental Microbiology 48, 456-458.

DaHLE, H. K. (1971). The purification and some properties of two Aeromonas proteinases. Acta pathologica, microbiologica et immunologica scandinavica B79, 726-738.

Denis, F. \& Veillet-Poncet, L. (1984). Purification partielle du systeme proteolytique extracellulaire de Aeromonas hydrophila LP50: étude comparative chromatographique et electrophoretique. Annales de microbiologie (Institut Pasteur) 135A, 219-227.

Fyfe, L., Coleman, G. \& Munro, A. L. S. (1987). Identification of major common extracellular proteins secreted by Aeromonas salmonicida isolated from diseased fish. Applied and Environmental Microbiology 53, 722-726.

Gross, R. \& COLES, N. W. (1969). A proteinase produced by Aeromonas hydrophila. Australian Journal of Science 31, 330-331.

HowARD, S. P. \& BuCKLEY, J. T. (1985). Activation of the hole-forming toxin aerolysin by extracellular processing. Journal of Bacteriology 163, 336-340.

KanaI, K. \& WaKabayashi, H. (1984). Purification and some properties of proteases from Aeromonas hydrophila. Bulletin of the Japanese Society of Scientific Fisheries 40, 1367-1374.

LAEMMLI, U. K. (1970). Cleavage of structural proteins during assembly of the head of bacteriophage T4. Nature, London 227, 680-685.

LEUNG, K.-Y. (1987). The role of proteases of Aeromonas hydrophila in infections of rainbow trout. $\mathrm{PhD}$ thesis, University of Guelph, Ontario, Canada.

Ljungh, A. \& WADSTROM, T. (1982). Aeromonas toxins. Pharmacology and Therapeutics 15, 339-354.

NiETo, T. P. \& ElLIS, A. E. (1986). Characterization of extracellular metallo- and serine-proteases of Aeromonas hydrophila strain $\mathbf{B}_{51}$. Journal of General Microbiology 132, 1975-1979.

PoPOFF, M. (1984). Aeromonas. In Bergey's Manual of Systematic Bacteriology, vol. 1, pp. 545-548. Edited by N. R. Krieg. Baltimore: Williams \& Wilkins.

SAKAI, D. K. (1985a). Loss of virulence in a proteasedeficient mutant of Aeromonas salmonicida. Infection and Immunity 48, 146-152.

SAKAI, D. K. (1985b). Significance of extracellular protease for growth of a heterotrophic bacterium, Aeromonas salmonicida. Applied and Environmental Microbiology 50, 1031-1037.

Thune, R. L., Graham, T. E., Riddle, L. M. \& AMBORSKI, R. L. (1982). Extracellular proteases from Aeromonas hydrophila: partial purification and effects on age- 0 channel catfish. Transactions of the American Fisheries Society 111, 749-754.

Trust, T. J. (1986). Pathogenesis of infectious diseases of fish. Annual Review of Microbiology 40, 479-502. 